\title{
KERAGAAN USAHA DAN STRATEGI PENGEMBANGAN PETERNAKAN AYAM RAS PEDAGING
}

\section{BUSSINES PERFORMANCE AND DEVELOPMENT STRATEGY OF BROILER FARM}

\author{
D. Fatmawati ${ }^{1}$, S. Masitoh ${ }^{1 \mathrm{a}}$ dan I. Novita ${ }^{1}$ \\ ${ }^{1}$ Program Studi Agribisnis, Fakultas Pertanian, Universitas Djuanda Bogor \\ Jalan Tol Ciawi 1, Kotak Pos 35 Bogor 16720 \\ ${ }^{a}$ Korespondensi: Siti Masithoh Telp: 0817404973; E-mail: sitimasitoh@unida.ac.id
}

\begin{abstract}
This research aims to know business performance, internal factors and external factors, and alternative strategy of broiler farms. This research was conducted from august to November 2017 in Parung District, Bogor Regency. A data analysis method of income measurement and SWOT w used. Eleven farmers were selected as respondent. Results showed that business performace includes, preperation preproduction, means of production livestock, skales maintance, marketing, harvesting, the income of farming, and farms of coperaton. Internal factors that become strength of the first rapid broiler growth. Internal factors that become the first weakness namely chicken mortality rate high. Eksternal factors that become the first opportunity the potencial market was wide open. Eksternal factors that become the first threath its broiler vulnerable contracted the desease. Alternative strategy is following the public of broiler farms.
\end{abstract}

Keywords: Broiler farm, SWOT Analysis, Development Strategy

\begin{abstract}
ABSTRAK
Tujuan penelitian ini adalah untuk mengetahui keragaan usaha, faktor internal dan eksternal serta strategi alternatif usaha peternakan ayam ras pedaging di Kecamatan Parung, Kabupaten Bogor. Hasil penelitian ini menunjukkan peluang dalam usaha ayam pedaging adalah kemudahan bahan baku dan pertumbuhan penduduk; ancamannya yaitu harga pakan tidak stabil, rentannya terjangkit penyakit, dan harga jual fluktuatif; kekuatannya adalah hubungan baik dengan pemasok, usaha turun temurun dan pertumbuhannya cepat; kelemahannya yaitu modal terbatas, sangat tergantung kepada pedagang pengumpul dan teknologi masih sederhana. Skor bobot rata-rata matriks IFE 2, 511 dan matriks EFE 3,045. Matriks IE pada usaha peternakan ayam ras pedaging di Kecamatan Parung terletak pada kuadran II, artinya berada pada tahap tumbuh dan kembangkan. Strategi pengembangnyanya melalui perluasan kandang, pengoptimalkan modal, peningkatkan kapasitas peternak, dan jalinan kemitraan.
\end{abstract}

Kata kunci : Ayam Ras Pedaging, Analisis SWOT, Strategi pengembangan.

\section{PENDAHULUAN}

Usaha di bidang peternakan yang paling banyak dilakukan di Indonesia adalah usaha ternak ayam ras pedaging. Total populasi ayam ras pedaging tahun 2014 sebanyak 1,44 miliar ekor dan pada tahun 2015 meningkat menjadi 1.5 miliar ekor (Kementrian Pertanian 2015).
Peningkatan tersebut merupakan respon dari konsumsi daging ayam ras yang selalu meningkat tiap tahunnya. Peningkatan konsumsi daging ayam disebabkan oleh berbagai faktor seperti kenaikan pendapatan perkapita, pertambahan penduduk, dan peningkatan pemahaman masyarakat mengenai pentingnya 
pemenuhan kebutuhan protein (Kementan, 2015).

Pengusahaan ayam ras pedaging memang potensial untuk dikembangkan, namun usaha ini membutuhkan modal yang cukup besar, baik modal investasi maupun modal operasional. Sementara itu pengusahaan ayam ras pedaging banyak dilakukan oleh peternak-peternak skala kecil yang memiliki keterbatasan modal. Keadaan ini mendorong terbentuknya karakteristik pengusahaan ayam ras pedaging yang berpola kemitraan. Pengusahaan ayam ras pedaging tersebar di hampir seluruh wilayah Indonesia. Provinsi yang dikenal sebagai sentra penghasil ayam ras terbesar di Indonesia adalah Jawa Barat, Jawa Timur, dan Jawa Tengah.

Provinsi Jawa Barat merupakan daerah penghasil ayam ras pedaging tertinggi di Indonesia. Produksi daging ayam ras Jawa Barat mencapai 47,12 persen dari keseluruhan produksi Indonesia. Kabupaten Bogor merupakan salah satu sentra produksi terbesar ayam ras pedaging di Provinsi Jawa Barat dengan produksi sebesar 106,007,918 (Dinas Peternakan Provinsi Jawa Barat 2015). Total produksi ayam ras pedaging di Kabupaten Bogor tahun 2015 sebesar 92.531.193. Produksi ayam ras pedaging di Kabupaten Bogor tersebar di 40 Kecamatan dengan rata-rata produksi perkecamatan 112.049.95. Kecamatan Parung merupakan salah satu daerah produsen ayam ras pedaging dengan produksi sebesar 4.481.998 (Dinas Perikanan dan Peternakan Kabupaten Bogor 2015).

Keragaan pola budidaya ternak ayam ras pedaging di Kecamatan Parung Kabupaten Bogor ditentukan oleh peternak tersebut, apakah budidaya secara mandiri ataupun kemitraan. Secara keseluruhan peternak di Kecamatan Parung mengusahakan ternaknya dengan budidaya secara mandiri dimana modal, kandang, peralatan, tenaga kerja, dan sarana produksi ternak ( DOC, pakan, obat, vaksin dan vitamin) serta memasarkan sendiri ternaknya.

Faktor yang mendorong peternak melakukan usaha dengan pola mandiri adalah keuntungan yang diperoleh peternak lebih maksimal, bebas memilih sapronak, dan memasarkannya secara mandiri. Oleh karena itu usaha ternak ayam broiler yang dilaksanakan di Kecamatan Parung perlu dikaji agar diketahui apa yang menjadi kekuatan, kelemahan, peluang dan ancaman usaha tersebut.

Penelitian ini bertujuan untuk mengetahui keragaan usaha, menganalisis lingkungan internal dan eksternal dan merumuskan alternatif strategi pengembangan usaha peternak ayam ras pedaging di Kecamatan Parung Kabupaten Bogor.

\section{BAHAN DAN METODE}

\section{Kerangka Pemikiran Teoritis}

Pendapatan peternak ayam ras pedaging sangat dipengaruhi oleh kombinasi penggunaan faktor-faktor produksi yaitu bibit ayam (DOC), pakan, obat-obatan, vitamin, dan vaksin, tenaga kerja, biaya listrik, bahan bakar, serta investasi kandang dan peralatan. Analisis pendapatan digunakan untuk mengetahui seberapa besar keuntungan atau pendapatan bersih yang diperoleh petani dari total biaya tetap (TFC), total biaya variabel (TVC) dan penerimaan. Pendapatan bersih dapat dihitung dengan menggunakan analisis pendapatan usaha. Analisis pendapatan usaha dapat dihitung dengan rumus (Suratiyah, 2015)

$$
\mathrm{I}=\mathrm{TR}-\mathrm{TC}
$$

Keterangan :

$$
\begin{array}{ll}
\mathrm{I} & =\text { Income }(\text { pendapatan) } \\
\mathrm{TR} & =\text { Total Revenue (penerimaan total) } \\
\mathrm{TC} & =\text { Total Cost (biaya total) }
\end{array}
$$

Kegiatan usahatani dianggap layak dijalankan jika nilai $\mathrm{R} / \mathrm{C}>1$ sedangkan usahatani tidak layak dijalankan jika nilai $\mathrm{R} / \mathrm{C}<1$ dan untuk $\mathrm{R} / \mathrm{C}=1$ pengusaha bisa 
memilih mau dilanjutkan atau tidak karena tidak terjadi keuntungan maupun kerugian (Suratiyah, 2015). Analisis R/C dihitung dengan rumus :

$$
\mathrm{R} / \mathrm{C}=\frac{\mathrm{TR}}{\mathrm{TC}}
$$

Keterangannya :

$\mathrm{TR}=$ Total Revenue (Penerimaan Total)

$\mathrm{TC}=$ Total Cost $($ Biaya Total $)$

Analisis R/C digunakan untuk mengetahui kesesuaian antara biaya yang dikeluarkan untuk kegiatan produksi dengan penerimaan yang diperoleh dari suatu usaha.

\section{Analisis SWOT}

Upaya peningkatan peternakan ayam ras pedaging sebagai bisnis tetap dilakukan, dengan tujuan meningkatkan pendapatan peternak dan adanya peluang kerja. Namun strategi apa yang dilakukan untuk meningkatkan usaha tersebut maka perlu dilakukan analisis SWOT yang terdiri dari faktor internal dan eksternal.

Menurut (David, 2011), SWOT adalah singkatan dari kekuatan (strengths) dan kelemahan (weaknesses) serta peluang (opportunities) dan ancaman (threats) dalam lingkungan suatu organisasi. Analisis SWOT adalah alat untuk mencocokkan yang penting untuk membantu manajer dalam mengembangkan empat tipe strategi yaitu: SO (kekuatan-peluang), WO (kelemahanpeluang), ST (kekuatan- ancaman), dan WT (kelemahan-ancaman). Matriks Strength-Weakness-Opportunity-Threat (SWOT) Matriks SWOT didasarkan pada asumsi bahwa strategi yang efektif akan memaksimalkan kekuatan dan peluang serta meminimalkan kelemahan dan ancaman. Kombinasi faktor-faktor internal dan eksternal dalam matriks SWOT terdiri atas strategi kekuatan-peluang (S-O), strategi kelemahan- peluang (W-O), strategi kelemahan-ancaman (W-T) dan strategi kekuatan- ancaman (S-T). Analisis matriks SWOT akan menghasilkan beberapa alternatif strategi yang dapat dipilih perusahaan dalam mengembangkan usahanya.

\section{Matriks IFE dan Matriks EFE}

Menurut David (2011), menyatakan bahwa matriks IFE (Internal Factor Evaluation) meliputi faktor-faktor internal organisasi sehingga dapat diketahui kekuatan dan kelemahan organisasi yang merupakan petunjuk dasar dalam menentukan posisi perusahaan. Hal yang sama juga berlaku pada matriks EFE (Eksternal Factor Evaluation) yang merupakan ringkasan dari ancaman dan peluang yang dihadapi organisasi. Matriks IFE dan EFE terdiri dari kolom bobot, rating, dan total nilai yang merupakan hasil kali dari bobot dan rating. Untuk kolom bobot dan rating diisi sesuai dengan nilainya yang merupakan hasil dari pengelompokan faktor-faktor internal dan eksternal berdasarkan tingkat kepentingannya.

Bobot setiap faktor diperoleh dengan menentukan nilai setiap faktor terhadap jumlah nilai keseluruhan faktor. Bobot yang diberikan pada setiap faktor berada pada kisaran 0,0 (tidak penting) hingga 1,0 (paling penting). Faktor-faktor yang dianggap mempunyai pengaruh besar pada prestasi perusahaan diberi bobot tertinggi, tanpa mempedulikan apakah faktor tersebut kunci kekuatan dan kelemahan serta peluang ancaman. Jumlah seluruh bobot yang diberikan pada setiap faktor harus sama dengan 1,0. Hal ini berlaku pada pembobotan faktor-faktor internal maupun eksternal. Bobot dari setiap faktor diperoleh dengan membagi jumlah nilai setiap variabel terhadap jumlah nilai keseluruhan variabel dengan menggunakan rumus sebagai berikut:

$$
\mathrm{Ai}=\frac{X i}{\sum_{i=1}^{i} X i}
$$

Keterangan:

ai $=$ Bobot faktor ke-i

$\mathrm{Xi}=$ Nilai faktor ke-i

$\mathrm{I}=1,2, \ldots, \mathrm{n}$ 
Penentuan rating menggambarkan seberapa besar efektivitas strategi yang diterapkan perusahaan saat ini dalam merespon faktor strategis yang ada (company-based). Penilaian rating diberikan dalam skala pembagian sebagai berikut :

$4=$ Sangat penting

$2=$ Penting

$3=$ Kurang penting

$1=$ Tidak penting

Perkalian Bobot dan Peringkat
Langkah selanjutnya, nilai dari pembobotan disusun dengan peringkat (rating) pada tiap faktor dan nilai tertimbang dari setiap faktor kemudian dijumlahkan untuk memperoleh total nilai tertimbang perusahaan. Matriks IFE merupakan alat untuk formulasi strategi untuk meringkas dan mengevaluasi kekuatan dan kelemahan utama dalam areal fungsional bisnis juga memberikan dasar untuk mengidentifikasi dan mengevaluasi hubungan area-area tersebut (David, 211). Dengan matriks IFE dapat diketahui kemampuan organisasi dalam menghadapi lingkungan internalnya dan mengetahui faktor-faktor internal yang penting.

Matriks EFE memungkinkan para penyusun strategi untuk merangkum dan mengevaluasi informasi ekonomi; sosial, budaya, demografis dan lingkungan; politik, pemerintah dan hukum; serta persaingan. Matriks EFE digunakan untuk mengetahui kemampuan perusahaan dalam menghadapi lingkungan eksternal. Matriks EFE terdiri dari kolom faktor eksternal utama, bobot, peringkat dan rata-rata tertimbang.

Total nilai tertimbang matrika IFE dan EFE akan berada pada kisaran 1,0 (terendah) hingga 4,0 (tertinggi), dengan nilai rata-rata 2,5. Semakin tinggi total nilai tertimbang perusahaan pada matriks IFE dan EFE mengindikasikan perusahaan merespon kekuatan dan kelemahan atau peluang dan ancaman dengan sangat baik, begitu pula sebaliknya. Matriks Internal-
Eksternal (IE) merupakan matriks yang meringkas hasil evaluasi faktor eksternal dan internal yang menempatkan perusahaan pada salah satu kondisi di dalam sembilan sel, dimana setiap sel merupakan kondisi langkah yang harus ditempuh perusahaan. Matriks IE didasarkan pada dua dimensi kunci: total rata-rata tertimbang IFE pada sumbu $X$ dan total rata-rata tertimbang EFE pada sumbu Y (David, 2011).

Matriks Internal-Eksternal (IE) Matriks IE berguna untuk memetakan posisi perusahaan. Matriks IE didasari pada dua dimensi, yaitu total nilai tertimbang IFE dan total nilai tertimbang EFE. Total nilai tertimbang IFE ditetapkan pada sumbu $\mathrm{x}$ dan total nilai tertimbang EFE pada sumbu y. Matriks IE mempunyai sembilan sel strategi, dapat dikelompokkan menjadi tiga sel strategi utama, yaitu:

Divisi pada sel I, II atau IV dapat melaksanakan strategi tumbuh dan kembangkan (growth and built). Strategi intensif (penetrasi pasar, pengembangan pasar dan pengembangan produk) atau integratif (integrasi ke belakang, integrasi ke depan, dan integrasi horisontal) merupakan strategi yang cocok untuk daerah ini. Divisi pada sel III, V dan VII dapat melaksanakan strategi mempertahankan dan pelihara (hold and maintain). Penetrasi pasar dan pengembangan produk merupakan dua strategi yang cocok digunakan. Divisi pada sel VI, VIII dan IX yaitu strategi panen dan melepaskan (harvest and divest). Strategi panen dan melepaskan merupakan strategi yang paling cocok digunakan pada daerah ini.

\section{Lokasi dan Pengumpulan Data}

Penelitian ini dilaksanakan di Kecamatan Parung Kabupaten Bogor Jawa Barat. Data yang dikumpulkan dalam penelitian ini meliputi data primer dan data sekunder. Data primer diperoleh melalui observasi langsung di lapangan dan wawancara langsung dengan peternak. Data sekunder diperoleh dari informasi 
tertulis yang berasal dari literatur-literatur yang relevan seperti buku, hasil penelitian terdahulu, informasi dari Dinas Peternakan, Badan Pusat Statistik, dan instansi yang dapat membantu ketersediaan data (Nazir, 2014).

Penentuan lokasi penelitian menggunakan metode purposive sampling.Purposive sampling adalah salah satu teknik pengambilan sampel secara sengaja dengan berbagai pertimbangan. Penentuan sampel untuk peternak ayam ras pedaging baik peternak pola mandiri atau peternak mitra menggunakan metode snowball sampling. Metode snowball sampling adalah teknik penentuan sampel yang mula-mula jumlahnya kecil kemudian membesar (Nazir, 2014).

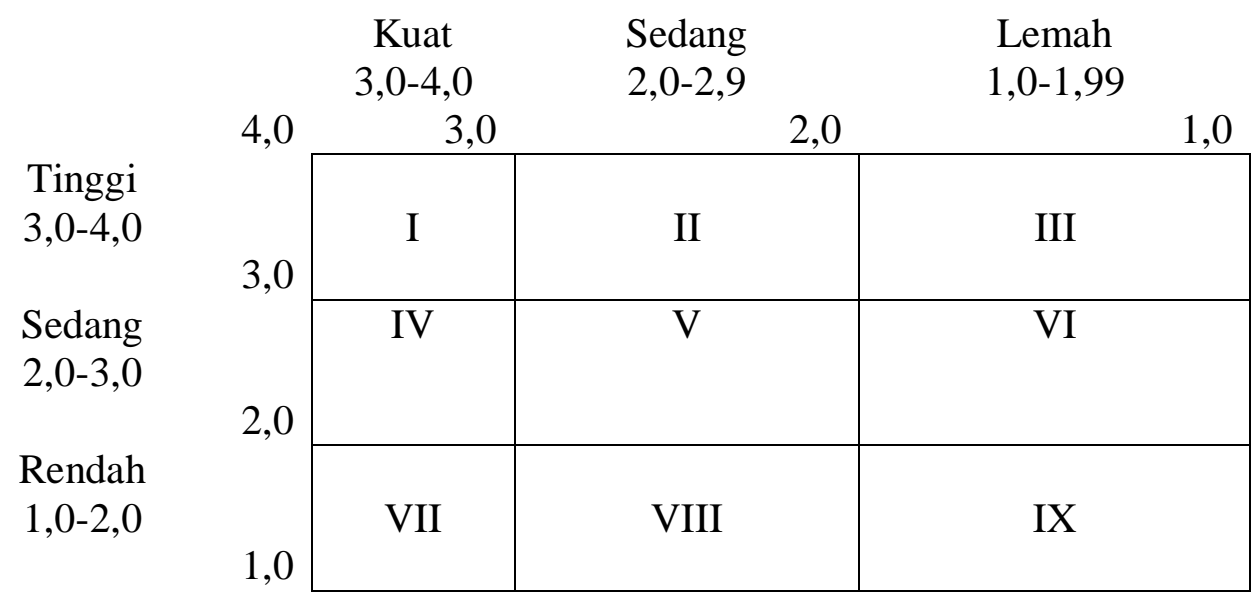

Gambar 1 Format Matriks Internal-Eksternal

\section{Metode Analisis}

Analisis data dilakukan dengan cara kualitatif dan data kuantitatif. Analisis deskriptif diperlukan untuk menganalisis data kualitatif sehingga dapat memberikan informasi yang mudah dimengerti. Analisis kualitatif dalam penelitian ini menggunakan analisis SWOT, matriks IFE, matriks EFE dan Matriks IE Analisis kuantitatif dilakukan dengan menggunakan perhitungan pendapatan usahatani dan R/C rasio. Analisis pendapatan usahatani digunakan untuk melihat besarnya pendapatan peternak ayam ras pedaging pada peternak mandiri. Sedangkan analisis $\mathrm{R} / \mathrm{C}$ rasio digunakan untuk melihat kelayakan usaha ternak ayam ras pedaging secara finansial. Data kuantitatif diolah Microsoft Office Excel.

\section{HASIL DAN PEMBAHASAN}

\section{Karakteristik Peternak}

Hasil penelitian menunjukkan bahwa mayoritas peternak mandiri usaha ayam ras pedaging berusia 40-49 tahun dengan persentase sebesar $46 \%$. Hal ini membuktikan bahwa kondisi peternak secara fisik di Kecamatan Parung memiliki potensi yang besar untuk usaha ternak ayam ras pedaging. Ada 2 orang peternak yang mengusahakan ayam ras pedaging di usia 50-59 tahun. Berdasarkan hasil sebaran kuisioner yang dilakukan di Kecamatan Parung Kabupaten Bogor menunjukkan bahwa rata-rata peternak yang melakukan budidaya ternak ayam ras pedaging yaitu kaum laki-laki karena kaum laki-laki berperan sebagai kepala keluarga yang mencari nafkah untuk kebutuhan hidup keluarga peternak dan menguasai teknik budidaya ternak ayam ras pedaging. Sebagian besar dari peternak ayam ras pedaging yang mempunyai tingkat pendidikan SMP dengan persentasi sebesar $55 \%$ atau sebanyak 6 orang dari total 11 peternak yang melakukan usaha ayam ras pedaging. Namun jumlah peternak yg lulusan SD $36 \%$ atau 4 orang dan jumlah peternak yang lulusan SMA hanya 1 orang atau $9 \%$. 
Mayoritas usaha yang dijalankan peternak mandiri merupakan usaha utama dengan persentase $73 \%$ dimana peternak mandiri yang ada di Kecamatan Parung menjalankan usaha ternak ayam ras pedaging didasarkan pada mata pencaharian utama. Alasan peternak menjalankan usahanya dikarenakan usaha ternak ayam ras pedaging ini bisa memperoleh keuntungan yang besar dengan persentasi $55 \%$ atau 6 orang peternak. Sebelas peternak mandiri yang ada di Kecamatan Parung mengusahakan ayam ras pedaging dengan skala pemeliharaan yang berbeda-beda, berkisar antara 1000-7000 ekor ayam. 64 persen peternak mandiri mengusahakan ternak ayam ras pedaging dengan skala pemeliharaan 1000-2000 ekor ayam. Status usaha ternak yang dijalankan oleh peternak ayam ras pedaging 11 orang dalam menjalankan usahanya berstatus peternak mandiri. Hal tersebut menunjukan bahwa usaha ternak ayam ras pedaging secara mandiri di Kecamatan Parung banyak diminati oleh peternak karena dengan usaha ternak secara mandiri keuntungan yang diperoleh lebih besar.

Pengalaman usaha peternak ayam ras pedaging yang ada di Kecamatan Parung rata-rata lebih dari 2 tahun.
Sebagian besar peternak mempunyai pengalaman usaha antara 1- 10 tahun sebanyak $45 \%$ atau 5 orang. Pengalaman usaha ternak anatara 11-20 tahun presentasinya sebesar 37 persen atau 4 orang dan masing-masing 9 persen untuk peternak yang mempunyai pengalaman usaha antara 21-30 tahun dan 31-40 tahun. Pengalam usaha ternak ayam yang cukup lama pada peternak sampel akan berpengaruh terhadap keberhasilan dalam menjalankan usaha ternaknya. Semakin lama peternak sampel begerak dalam usaha ternak ayam maka akan menjadi terbiasa dalam menghadapi berbagai masalah sehingga kegagalan dapat diatasi.

Seluruh peternak mandiri telah berkeluarga atau sudah menikah dengan tingkat persentasi 100 persen atau 11 orang. Hal tersebut menunjukkan bahwa usaha ternak ayam ras pedaging merupakan usaha yang dijalankan untuk memenuhi kebutuhan hidup keluarga.

\section{Keragaan Umum Usaha Ternak Ayam Ras Pedaging}

Keragaan umum usaha ternak ayam ras pedaging beserta analisis usahanya dapat dilihat pada Tabel 1 .

Tabel 1 Analisis Usaha Ternak Ayam Ras Pedaging di Kecamatan Parung Kabupaten Bogor

\begin{tabular}{ccccccc}
\hline Nama Peternak & $\begin{array}{c}\text { Jumlah } \\
\text { DOC }\end{array}$ & $\begin{array}{c}\text { Total } \\
\text { Panen } \\
(\text { Ekor) }\end{array}$ & $\begin{array}{c}\text { Total } \\
\text { Produksi } \\
(\mathrm{Kg})\end{array}$ & Total Biaya & $\begin{array}{c}\text { Total } \\
\text { Penerimaan }\end{array}$ \\
\hline 1 & Agus & 3000 & 2700 & 4050 & 58.832 .325 & 73.900 .000 \\
2 & Arman & 1800 & 1620 & 1944 & 31.027 .192 & 33.210 .000 \\
3 & Andibuang & 2000 & 1840 & 2208 & 39.742 .311 & 42.162 .000 \\
4 & Amung Sutisna & 1000 & 900 & 1260 & 21.395 .207 & 25.357500 \\
5 & Ahmad Junaedi & 2000 & 1950 & 2280 & 37.362 .292 & 43.470 .000 \\
6 & Badru & 4000 & 3840 & 5760 & 53.292 .052 & 104.000 .000 \\
7 & Dani & 2000 & 1800 & 2700 & 36.645 .281 & 51.550 .000 \\
8 & Ismatullah & 2000 & 1920 & 2304 & 35.155 .623 & 48.534 .000 \\
9 & Mansur & 2000 & 1850 & 1944 & 35.968 .000 & 37.046 .000 \\
10 & Syamsudin & 2000 & 1700 & 2210 & $38,260.488$ & 43.753 .000 \\
11 & Romli & 7000 & 6350 & 7980 & 115.911 .726 & 144.565 .000 \\
& Jumlah & 28300 & 26470 & 34640 & 465.370 .269 & 622.443 .575 \\
\hline & Rata-rata & 2572 & 2406 & 3149 & 42.306 .388 & 56.585 .779 \\
\hline
\end{tabular}


Keuntungan rata-rata yang diperoleh peternak dalam satu periode sebesar Rp. 13.012.235 . R/C Ratio rata-rata peternak ayam ras pedaging di Kecamatan Parung sebesar 1,25 dan usaha ini layak dilanjutkan. Penyusutan perperiode usaha peternakan ayam ras pedaging sebesar Rp. 491.962 dan harga jual peternak sebesar Rp. $15.563 / \mathrm{Kg}$

Tabel 2 Nilai Keuntungan, R/C, Penyusutan dan Harga Jual ayam ras pedaging di Kecamatan Parung Kabupaten Bogor

\begin{tabular}{cccccc}
\hline No & Nama Peternak & $\begin{array}{c}\text { Total Keuntungan } \\
(\mathrm{Rp})\end{array}$ & $\begin{array}{c}\text { R/C } \\
\text { Ratio }\end{array}$ & Penyusutan & $\begin{array}{c}\text { Harga Jual } \\
(\mathrm{Kg})\end{array}$ \\
\hline 1 & Agus & 14.247 .675 & 1,2 & 630,325 & Rp. 18.000 \\
2 & Arman & 2.182 .808 & 1,1 & 220,303 & Rp. 20.500 \\
3 & Andibuang & 2.419 .689 & 1,06 & 437,311 & Rp. 19.000 \\
4 & Amung Sutisna & 3.962 .293 & 1,2 & 553,207 & Rp. 20.000 \\
5 & Ahmad Junaedi & 6.107 .708 & 1,2 & 291.790 & Rp. 19.000 \\
6 & Badru & 50.707 .948 & 1,9 & 260,552 & Rp. 18.000 \\
7 & Dani & 14.904 .719 & 1,4 & 266,821 & Rp. 19.000 \\
8 & Ismatullah & 13.378 .377 & 1,4 & 243,623 & Rp. 21.000 \\
9 & Mansur & 1.077 .586 & 1 & 708,414 & Rp. 19.000 \\
10 & Syamsudin & 5.492 .512 & 1,14 & 487,515 & Rp. 19.700 \\
11 & Romli & 28.653 .274 & 1,2 & 1.011 .726 & Rp. 18.000 \\
& Jumlah & 143.134 .589 & 13,8 & 5.411 .587 & Rp. 171.200 \\
\hline & Rata-rata & 13.012 .235 & 1,25 & 491.962 & Rp. 15.563 \\
\hline
\end{tabular}

\section{Analisis Faktor Internal dan Faktor Eksternal}

Kekuatan Usaha Ternak Ayam Ras Pedaging terletak pada hubungan yang baik antara peternak dengan pihak pemasok karena rata-rata peternak ayam ras pedaging memperoleh sarana produksi ternak ke pihak pemasok dan bahkan bisa menjual hasil panen ke pemasok. Selain bisa menjual hasil panen para peternak juga diperbolehkan membayar sapronak setelah panen. Usaha ternak ayam broiler yang dijalankan oleh ke sebelas peternak rata-rata usaha tersebut dilakukan secara turun temurun.

Peternak lebih mahir dalam menjalankan usahanya hal ini disebabkan peternak sudah terbiasa membantu kedua orang tuaanya dalam menjalankan usaha ternaknya. Kelemahan Usaha Ternak
Ayam Ras Pedaging terletak pada modal yang dimiliki oleh peternak mandiri ratarata terbatas. Rata-rata modal tersebut diperoleh dari simpanan pribadi karena ada usaha sampingan, diperoleh dari Bank, diperoleh dari keuntungan selama menjalankan usaha. Peternak yang ada di Kecamatan Parung sangat tergantung kepada pedagang pengumpul karena ratarata peternak berhutang kepada pihak pengumpul untuk pembelian DOC atau sarana ternak lainnya seperti sekam ataupun pakan. Angka kematian atau mortalitas peternak ayam ras pedaging di daerah penelitian rata-rata $11 \%$. Tingkat kematian tersebut termasuk tingkat kematian yang sangat besar karena melebihi $5 \%$. Apabila terus-terusan angka kematian tinggi maka hasil produksi ayam ras pedaging menjadi berkurang. 
Tabel 3 Analisis faktor internal usaha ternak ayam ras pedaging

\begin{tabular}{|c|c|}
\hline \multicolumn{2}{|c|}{ Faktor Internal } \\
\hline Kekuatan & Kelemahan \\
\hline $\begin{array}{l}\text { - Berhubungan baik dengan pemasok } \\
\text { - Usaha turun temurun } \\
\text { - Pertumbuhan ayam ras pedaging cepat }\end{array}$ & $\begin{array}{l}\text { - Modal terbatas } \\
\text { - Sangat tergantung pada pihak pengumpul } \\
\text { - Teknologi masih sederhana }\end{array}$ \\
\hline
\end{tabular}

Sumber : Data Primer (diolah), 2018

Analisis Lingkungan Eksternal meliputi faktor peluang dan ancaman dalam usaha ayam ras pedaging. Faktor peluang meliputi potensi pasar terbuka lebar dikarenakan daging ayam ras pedaging akan selalu dibutuhkan dengan seiring meningkatnya kesadaran masyarakat akan gizi, kemajuan teknologi sehingga banyak tercipta berbagai macam produk olahan yang berbahan dasar daging ayam ras. Konsumsi daging ayam tinggi dikarenakan masyarakat sadar akan kebutuhan gizi dan setiap tahun penduduk di Indonesia selalu meningkat. Sedangkan faktor ancaman terletak pada DOC dan pakan merupakan faktor produksi pertama dalam usaha peternakan ayam ras pedaging. Peternak tidak dapat menurunkan harga yang sudah ditetapkan oleh pemasok dan peternak tidak dapat memprediksi harga DOC dan Pakan pada periode yang akan datang. Harga DOC yang fluktuatif dan pakan yang terus naik menjadi ancaman besar bagi peternak ayam ras pedaging di Kecamatan Parung Kabupaten Bogor. Usaha ternak ayam ras pedaging tidak terlepas dari wabah penyakit. Penyakit yang muncul pada usaha ternak ayam ras pedaging di Kecamatan Parung seperti ecoli, gumboro (IBD), dan tetelo (ND), Ketiga penyakit tersebut merupakan penyakit yang sering menyebabkan kematian pada usaha ternak ayam ras pedaging.

\section{Matriks EFE}

Peluang pada usaha ternak ayam ras pedaging di Kecamatan Parung adalah potensi pasar terbuka lebar dengan skor bobot 0,6720. Keberadaan akan daging ayam akan selalu dibutuhkan seiring dengan meningkatnya kesadaran masyarakat akan pentingnya protein hewani Daging ayam juga sangat dibutuhkan seiirng meningkatnya teknologi, sehingga banyak tercipta produk-produk olahan yang berbahan dasar daging ayam. Data tersebut dapat dilihat pada Tabel 3. Ancaman utama pada usaha ternak ayam ras pedaging adalah rentannya ayam ras pedaging terjangkit penyakit dengan skor bobot 0,6678. Rata-rata tingkat kematian pada usaha ternak ayam ras pedaging di Kecamatan Parung sebesar $11 \%$ hal tersebut disebabkan perubahan musim yang mengakibatkan ayam ras pedaging banyak terserang penyakit sehingga banyak ayam yang mati dalam satu periode.

\section{Matriks IFE}

Kekuatan dan kelemahan usaha peternakan ayam ras pedaging di Kecamatan Parung digambarkan pada Tabel 5. Kekuatan utama usaha peternakan ayam ras pedaging di Kecamatan Parung adalah variabel kekuatan memiliki nilai skor bobot terbesar 0,493 yaitu pertumbuhan ayam ras pedaging cepat. Rata-rata peternak ayam ras pedaging di Kecamatan Parung memilih mengusahan ternak ayam ras pedaging dikarenakan masa panen ayam ras pedaging singkat atau dalam kurun waktu 28 hari peternak bisa langsung panen. Sedangkan kelemahan utama usaha peternakan ayam ras pedaging adalah sangat tergantung pada pihak pengumpul dengan skor bobot 0,5886 karena hasil panen ayam ras pedaging bisa dijual keseluruhan ke pedagang pengumpul 
hal tersebut menjadi alasan peternak bergantung kepada pihak pengumpul.

\section{Matriks IE}

Setelah diperoleh total skor dari matriks IFE sebesar 2,9625 dan nilai skor matriks EFE sebesar 3,1686 hasil skor tersebut dapat menunjukan posisi usaha ternak ayam ras pedaging di Kecamatan Parung melalui matriks IE. Adapun matriks IE untuk usaha peternakan ayam ras pedaging di Kecamatan Parung ditujukan pada Gambar 3. Gambar tersebut menunjukan bahwa posisi usaha ternak ayam ras pedaging di Kecamatan Parung berada pada kuadran II yaitu tumbuh dan kembangkan. Menurut David (2011), Pada Kuadran II dapat melaksanakan strategi tumbuh dan kembangkan (growth and built). Strategi intensif (penetrasi pasar, pengembangan pasar dan pengembangan produk) atau integratif (integrasi ke belakang, integrasi ke depan, dan integrasi horisontal) merupakan strategi yang cocok untuk daerah ini.

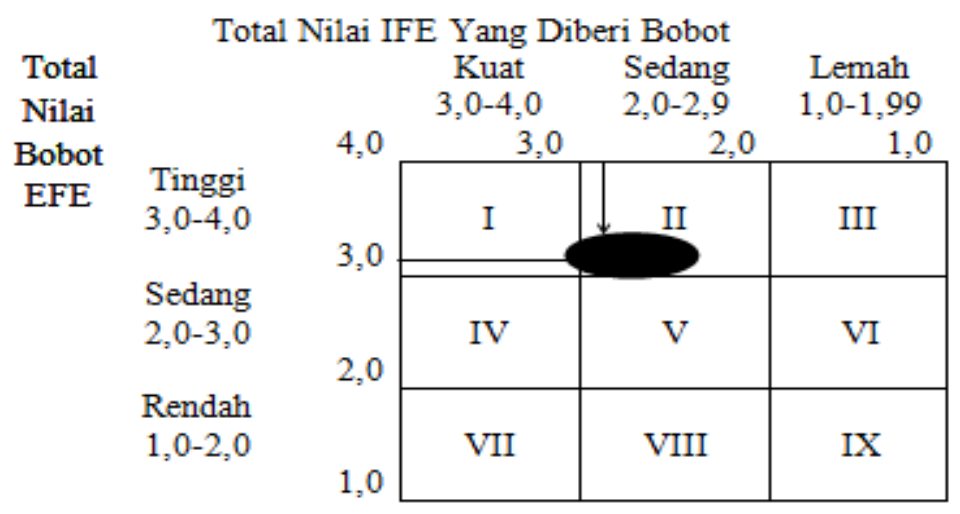

\section{KESIMPULAN DAN IMPLIKASI KEBIJAKAN}

\section{Kesimpulan}

Usaha yang dijalankan oleh peternak sebanyak 11 orang di Kecamatan Parung diusahakan secara mandiri. Mandiri berarti usaha yang dijalankan sapronak, modal, tenaga kerja dari peternak itu sendiri. Rata-rata $\mathrm{R} / \mathrm{C}$ ratio yang didapat dari pendapatan usaha ternak sebesar 1,2 dan usaha ini layak dijalan kan. Tingkat kematian ternak ini sebanyak $11 \%$ dimana angka kematian ini sangat berpengaruh besar terhadap usaha peternakan ayam ras pedaging yang ada di Kecamatan Parung.

Berdasarkan analisis lingkungan eksternal dan internal usaha peternakan ayam ras pedaging diperoleh yang menjadi faktor-faktor kekuatan usaha peternakan ayam ras pedaging di Kecamatan Parung yaitu berhubungan baik dengan pemasok, usaha turun temurun, dan pertumbuhan ayam ras pedaging cepat. Dan yang menjadi kelemhannya yaitu modal terbatas, sangat tergantung kepada pihak pengumpul dan Tingkat kematian tinggi. Sementara faktor eksternal yang dijadikan sebagai peluang adalah potensi pasar terbuka lebar dan pertumbuhan penduduk. Dan faktor yang menjadi ancaman yaitu harga pakan ternak yang tidak stabil harganya, rentannya ayam ras pedaging terjangkit penyakit dan harga jual fluktuatif. Skor bobot rata-rata Matriks IFE 2,9625 sebesar dan skor bobot rata-rata matriks EFE sebesar 3,1686. Matriks IE pada usaha peternakan ayam ras pedaging di Kecamatan Parung terletak pada kuadran I yaitu Tumbuh dan Kembangkan.

Alternatif strategi pengembangan usaha peternakan ayam ras pedaging berturut-turut adalah peningkatan produksi melalui perluasan kandang dengan lahan yang tersedia, mengoptimalkan modal usaha dan meningkatkan kemampuan 
usaha ternak ayam ras pedaging, mengikuti pelatihan atau seminar-seminar sebagai wawasan tambahan mengenai penanganan penyakit pada ayam, melakukan pengendalian dan pengawasan terhadap penyakit ternak agar usaha peternakan bisa berkelanjutan dan menjalin kemitraan antara peternak dengan pihak mitra sehingga ada modal, pelatihan budidaya dan pengawasan dari pihak perusahaan mitra.

\section{Implikasi Kebijakan}

Peternak dapat melakukan urutan pelaksanaan strategi dengan baik dan terencana berdasarkan alternatif strategi yang telah tersusun. Yang pertama peningkatan produksi melalui kandang dan lahan yang tersedia. Peternak bisa bekerjasama dengan pihak mitra untuk mendapatkan kemudahan modal, pengawasan terhadap penyakit ayam dari pihak perusahaan mitra dan harga yang diterima peternak tidak fluktuatif.

\section{Daftar Pustaka}

Amelia R. 2012. Analisis Risiko Produksi Ayam Ras Pedaging Pada Peternakan Bapak Maulid di Kelurahan Karang Anyar Kecamatan Bukit Baru Kota Palembang. Skripsi. Bogor : Institut Pertanian Bogor.

Anandra, A. R. 2010. Analisis Efisiensi Penggunaan Faktor Faktor Produksi Pada Usaha Ternak Ayam Ras Pedaging Di Kabupaten Magelang. Fakultas Ekonomi. Universitas Diponegoro. Semarang.

Ajizah, Suf. 2017. Analisis Usaha dan Strategi Pengembangan Usaha Ternak Ayam Ras Petelur Di Kecamatan Gadingrejo Kbupaten Pringsewu. Skripsi. Bandar Lampung.

Badan Pusat statistik Kabupaten Bogor. 2017. Kecamatan Parung Dalam Angka 2017. Bogor.
Daryanto, A. 2009. Dinamika Daya Saing Peternakan. IPB Press: Bogor.

David, Fred R. 2011. Manajemen Strategis Konsep. Salemba Empat. Jakarta

Deshinta, M. 2006. Peranan Kemitraan Terhadap Peningkatan Pendapatan Peternak Ayam Broiler, Kasus Kemitraan : PT. Sierad Produce dengan Peternak Di Kabupaten Sukabumi. Skripsi. Institut Pertanian Bogor. Bogor.

Deslirizaldi. 2011. Analisis Usaha Ternak Perah Rakyat Di Kota Padang Panjang. Tesis. Universitas Andalas. Padang.

Dinas Peternakan Provinsi Jawa Barat . 2017 Populasi Ternak Ayam Ras Pedaging Provinsi Jawa Barat Tahun . Bandung

Jummiati. 2017. Strategi Pengembangan Usaha Peternakan Ayam ras Pedaging Kecamatan Rambah Kabupaten Rokan Hulu. Artikel Ilmiah. Universitas Pair Pangairan. Riau.

Kementrian Pertanian Republik Indonesia. 2017. Populasi dan Produksi Peternakan di Indonesia. Jakarta.

Kurniawan, H. 2011. Strategi Pengembangan Ayam Ras Petelur di Kota Samarinda Kalimantan Timur. Jurnal Peternakan. Volume 35 No 1:57-63. Diakses pada Tanggal 2 Oktober 2016.

Moh. Nazir. 2014. Metode Penelitian. Ghalia Indonesia.Bogor.

Nurfadillah, N. 2014. Keragaan Usaha Ayam Ras Pedaging Di Kecamatan Parung Bogor : Perbandingan Usaha Ternak Mitra dan Usaha Ternak Mandiri. Skripsi.Institut Pertanian bogor. Bogor

Pinto B. 2011. Analisis Risiko Produksi pada Peternakan Ayam ras pedaging Milik Bapak Restu Di Desa Cijayanti, Kecamatan 
Babakan Madang, Kabupaten Bogor. Skripsi. Institut Pertanian Bogor. Bogor.

Pribadi, K. 2013. Analisis Pelaksanaan Kemitraan Ayam Broiler Pada CV Barokah dan Pendapatan Antara Peternak Mitra dan Peternak Mandiri. Skripsi. Institut Pertanian Bogor. Bogor.

Pusat Data dan Sistem Informasi Pertanian Kementrian Pertanian. 2017. Daging Ayam. Pusat Data dan Sistem Informasi Pertanian Kementrian Pertanian. Jakarta.

Pusat Data dan Sistem Informasi Pertanian. 2017. Sentra Produksi Ayam Ras Pedaging di Indonesia. 2017. Jakarta.

Pusat Data dan Sistem Informasai Pertanian 2017 . Analisis PDB Sektor Pertanian Tahun 2017. Jakarta.

Rahim, Abd dan Hastuti, DRW. 2007.

Ekonomi Pertanian. Penebar Swadaya. Sinar Tani. Jakarta.

Rasyaf, M. 2010. Beternak Ayam Pedaging. Cetakan ke-26. Penebar Swadaya. Jakarta.

Rustam, AR dan Rosida, PA. 2014. Strategi Pengembangan Usaha Ternak Ayam Ras Pedaging Di Provinsi Sulawesi Tengah. Jurnal. Sulawesi Tengah.

Rangkuti, freddy. SWOT Balanced Scorecard. 2011. Teknik
Menyusun Strategi Korporat yang efektif plus Cara Mengelola Kinerja dan Risiko. Gramedia Pustaka Utama.

Sari DP. 2012. Analisis Pendapatan Usaha Ternak Ayam Ras Pedaging Pola Kemitraan Dan Mandiri Di Kecamatan Gunung Sindur Kabupaten Bogor. Skripsi. Departemen Ekonomi Sumberdaya dan Lingkungan Fakultas Ekonomi dan Manajemen Institut Pertanaian Bogor: Bogor

Santoso dan Sudaryani, T .2009. Pembibitan Ayam Ras. Bogor: PT. Penebar Swadaya.

Sirajuddin, SN. Ranggadatu, M. Siregar, AR. 2012. Bagi hasil kemitraan ayam pedaging pada pt. $X$ di Kabupaten Maros Propinsi Sulawesi Selatan.

Solihin M. 2009. Risiko Produksi dan Harga serta Pengaruhnya terhadap Pendapatan Peternakan Ayam ras pedaging $\mathrm{CV} A B$ Farm Kecamatan Bojonggenteng - Sukabumi. Skripsi. Institut Pertanian Bogor. Bogor

Sumardjo, Sulaksana J, Darmono WA. 2010. Teori dan Praktik Kemitraaan Agribisnis. Penebar Swadaya. Jakarta 
Lampiran 1 Tabel Analisis Faktor Eksternal dan Internal usaha ternak ayam ras pedaging

Analisis Faktor Eksternal usaha ternak ayam ras pedaging

\begin{tabular}{|c|c|c|c|}
\hline Faktor Eksternal & Rating Rata-rata & Bobot Rata-rata & $\begin{array}{c}\text { Skor Bobot } \\
\text { Rata-rata }\end{array}$ \\
\hline \multicolumn{4}{|l|}{ Peluang } \\
\hline $\begin{array}{l}\text { Potensi pasar } \\
\text { terbuka lebar }\end{array}$ & 3,36 & 0,20 & 0,6720 \\
\hline $\begin{array}{l}\text { - Pertumbuhan } \\
\text { penduduk }\end{array}$ & 2,82 & 0,22 & 0.6204 \\
\hline \multicolumn{4}{|l|}{ Ancaman } \\
\hline $\begin{array}{l}\text { Harga pakan dan } \\
\text { DOC yang tidak } \\
\text { stabil }\end{array}$ & 3,09 & 0,21 & 0,6489 \\
\hline $\begin{array}{l}\text { - Rentannya ayam ras } \\
\text { pedaging terjangkit } \\
\text { penyakit }\end{array}$ & 3,18 & 0,21 & 0,6678 \\
\hline \multirow[t]{2}{*}{ - Harga jual fluktuatif } & 3,73 & 0,15 & 0,5595 \\
\hline & & & 3.1686 \\
\hline
\end{tabular}

Sumber : Data Primer (diolah), 2018

Analisis Faktor Internal usaha ternak ayam ras pedaging

\begin{tabular}{lccc}
\hline Faktor Internal & Rating & Bobot & Skor Bobot \\
\hline Kekuatan & & & \\
\hline $\begin{array}{l}\text { Berhubungan } \\
\text { baik dengan } \\
\text { pemasok }\end{array}$ & 2,8 & 0.17 & 0,476 \\
- $\begin{array}{l}\text { Usaha turun } \\
\text { temurun }\end{array}$ & 3 & 0.16 & 0,48 \\
- Pertumbuhan \\
$\begin{array}{l}\text { ayam ras } \\
\text { pedaging cepat }\end{array}$ & 2,9 & 0.17 & 0.493 \\
\hline Kelemahan & 3,09 & 0.13 & 0.4017 \\
\hline Modal terbatas & 3,27 & 0.18 & 0.5886 \\
- Sangat \\
$\begin{array}{l}\text { tergantung } \\
\text { kepada pihak } \\
\text { pengumpul }\end{array}$
\end{tabular}


Lampiran 2 Matriks SWOT usaha peternakan ayam ras pedaging di Kecamatan Parung Kabupaten Bogor

\begin{tabular}{|c|c|c|}
\hline Faktor Eksternal & 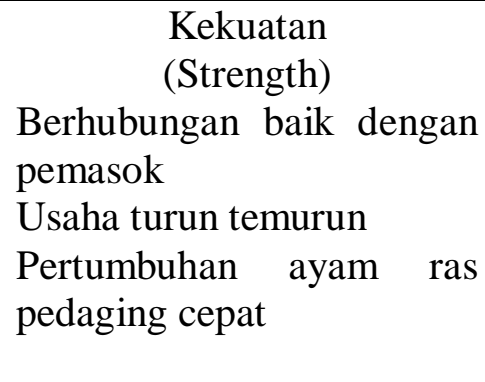 & $\begin{array}{l}\qquad \begin{array}{l}\text { Kelemahan } \\
\text { (Weaknes) }\end{array} \\
\text { Modal terbatas } \\
\text { Sangat tergantung kepada pihak } \\
\text { pengumpul } \\
\text { Tingkat kematian tinggi }\end{array}$ \\
\hline $\begin{array}{l}\text { Peluang } \\
\quad \text { (Opportunity) } \\
\text { - Potensi pasar terbuka } \\
\text { lebar } \\
\text { - Pertumbuhan penduduk }\end{array}$ & $\begin{array}{l}\text { Strategi S-O } \\
\text { 1. Peningkatan produksi } \\
\text { melalui perluasan } \\
\text { kandang dengan lahan } \\
\text { yang tersedia. }\end{array}$ & \begin{tabular}{l}
\multicolumn{1}{c}{ Strategi W-O } \\
1. Mengoptimalkan modal \\
usaha dan meningkatkan \\
kemampuan usaha ternak \\
ayam ras pedaging.
\end{tabular} \\
\hline \begin{tabular}{l}
\multicolumn{1}{c}{ Ancaman } \\
$\quad$ (Threat) \\
- Harga pakan dan DOC \\
yang tidak stabil \\
- Rentannya ayam ras \\
pedaging terjangkit \\
penyakit \\
- Harga jual fluktuatif
\end{tabular} & $\begin{array}{l}\text { Strategi S-T } \\
\text { a. Mengikuti pelatihan atau } \\
\text { seminar-seminar sebagai } \\
\text { wawasan tambahan } \\
\text { mengenai penanganan } \\
\text { penyakit pada ayam. } \\
\text { b. Malakukan } \\
\text { pengendalian dan } \\
\text { pengawasan terhadap } \\
\text { penyakit ternak agar } \\
\text { usaha peternakan bisa } \\
\text { berkelanjutan. }\end{array}$ & $\begin{array}{l}\quad \text { Strategi W-T } \\
\text { 1. Menjalin kemitraan antara } \\
\text { peternak dengan pihak mitra } \\
\text { sehingga ada modal, } \\
\text { pelatihan budidaya dan } \\
\text { pengawasan dari pihak } \\
\text { perusahaan mitra. }\end{array}$ \\
\hline
\end{tabular}

